\title{
AN EFFECT OF THE EPIDIDYMIS ON THE GROWTH OF ANTLERS OF CASTRATED RED DEER
}

\author{
G. A. LINCOLN \\ MRC Unit of Reproductive Biology, \\ 2 Forrest Road, Edinburgh EH1 2QW
}

(Received 2nd Fuly 1974)

The antlers of red deer, Cervus elaphus, are cast in the spring and a new set develop during the summer months. This cycle of antler renewal is controlled by seasonal changes in testosterone secretion by the testes (Lincoln, Youngson \& Short, 1970; Lincoln, 1971). Low levels of circulating testosterone are associated with the casting and regrowth of the antlers, while the high androgen levels in late summer and autumn lead to the maturation of the new antler and the associated shedding of velvet.

During the period of antler growth, testosterone is present in the peripheral blood of stags in very low concentrations $(>200 \mathrm{pg} / \mathrm{ml})$, but the hormone is physiologically active at this time and is associated with the normal development of the fully formed antler. If the testosterone levels are artificially modified by castration or hormonal therapy, abnormal antlers are produced (see Pl. 1, Fig. 2 and Pl. 1, Fig. 3), indicating that antler morphology is a sensitive indicator of androgen secretion.

Using this bioassay system, it has been possible to investigate whether the epididymis of stags secretes significant amounts of androgens. A number of studies in laboratory species have indicated that the epididymis may actively synthesize sex steroids, including testosterone (Hamilton \& Fawcett, 1970; Frankel \& Eik-Nes, 1970; Hamilton, 1972). It has not been established, however, whether this organ ever secretes such hormones into epididymal fluids or into the peripheral circulation.

The present study involved six adult stags which were living wild on the Island of Rhum off the west coast of Scotland. Five of these animals were surgically castrated after sedation with etorphine (M99: Reckitt \& Sons, Hull) at various times during the autumn and winter, and both testes and epididymides were removed (Lincoln et al., 1970; Lincoln, Guinness \& Short, 1972). The sixth animal, a 7-year-old stag, was castrated in December but the epididymides were left intact. Particular care was taken to remove all traces of the testicular tissue and not to damage the blood supply to the epididymis.

Each of the six stags made an uneventful recovery. They cast their existing antlers 16 to 20 days after castration, and the new antlers that developed remained permanently in velvet (Table 1). Relatively normal antlers were, however, produced only by the animal in which the epididymides remained. The antlers were very similar to those grown the previous year as an intact stag, although one brow tine was imperfectly formed (Pl. 1, Fig. 1) The other 


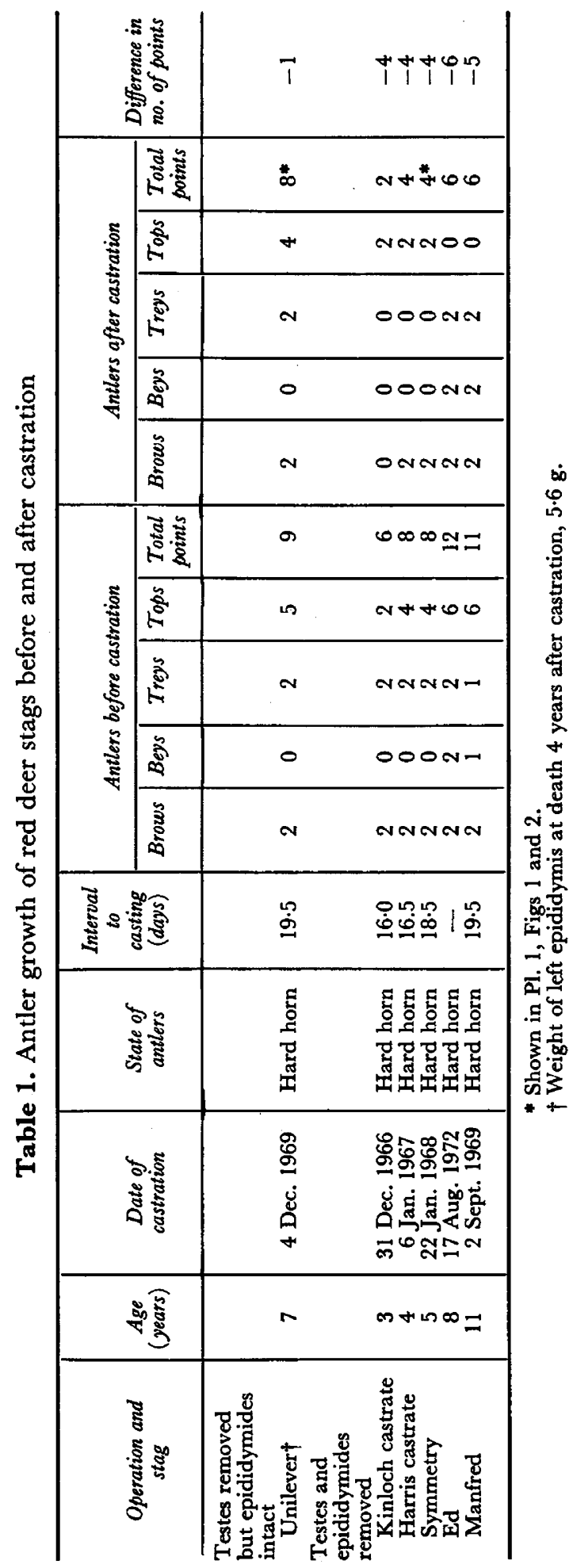


PIATE 1
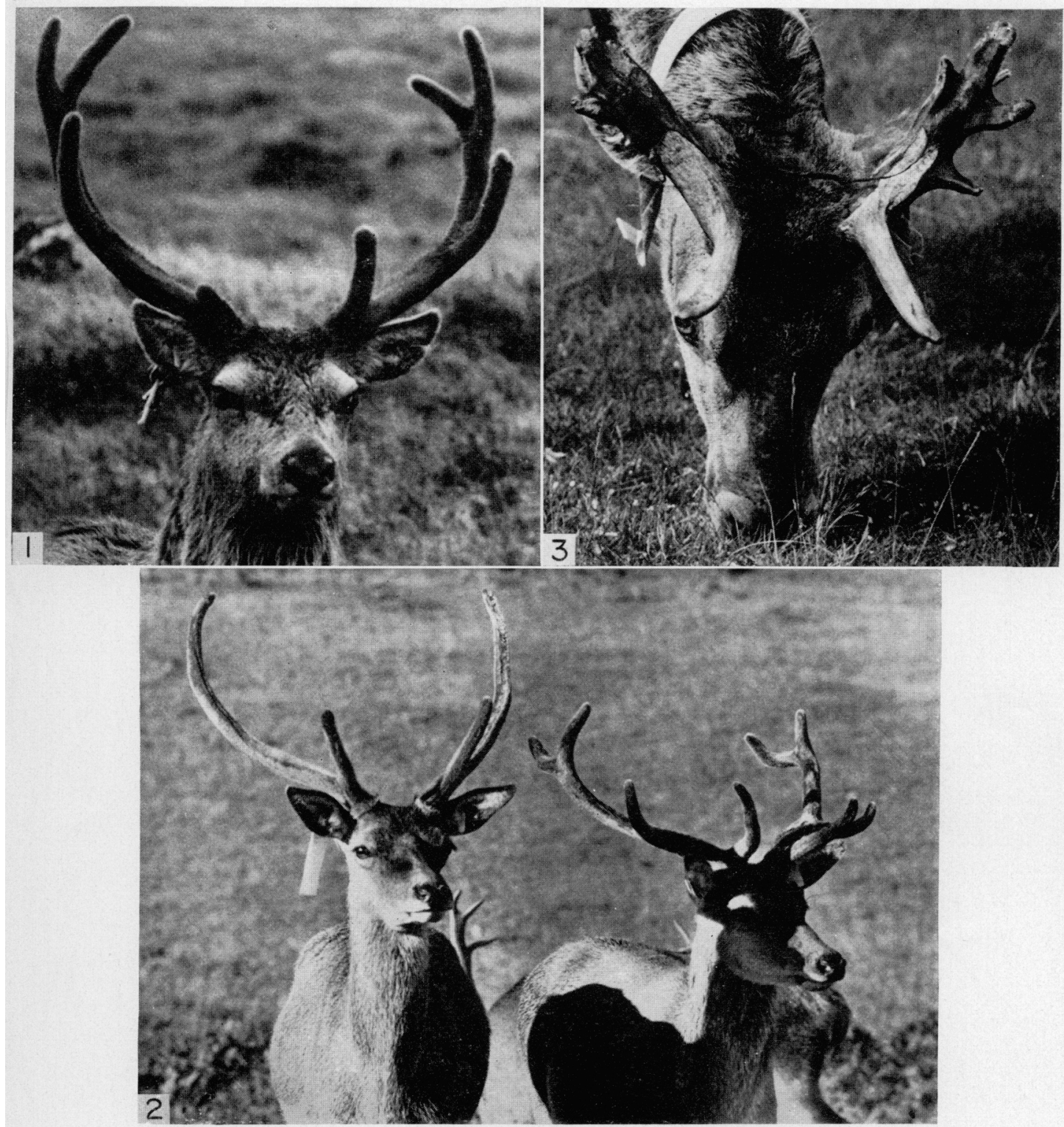

lir . 1. Red deerstag. Unilever, castrated at 7 years of age but with the epididymides left intact. showing (17 $\mathrm{A}$ pril 1970$)$ relatively normal antler development including branching of the tops. This animal retained its antlers in velvet and behared like a castrated statg.

Fir: 2. Symmetry (left) castrated at 5 years of age. with both testes and epididymides removed, showing (17 Aug. 1968 ) antlers in velvet with brow tines but simple unbranched beams. The animal to the right is an intact stag with normal antlers.

Fic: 3. Stag (9 June 1970) implanted with 2 g testosterone shortly alter casting, when the anters were just beginning to grow in velvet (Lincoln et al.. 1972). The antlers were cleaned after 43 days but not before the upper antler points were prematurely dereloped. 
five castrated stags produced antlers with simple unbranched tops, the lower tines being best formed in the older animals (Pl. 1, Fig. 2; Table 1).

Since the antler development of the stag with intact epididymides was more normal than that of the five completely castrated animals, it seems likely that this individual had significantly higher concentrations of circulating androgens, presumably arising from the epididymides. The levels of such androgens must have remained relatively low because the stag retained its antlers in velvet and its behaviour was identical to that of a castrated stag.

The only other example on record of a castrated red deer stag producing branched tops to its antlers (except after breaking off the original growth and regrowing a branched section: Lincoln, 1970) was an animal on Rhum which had received a large implant of testosterone (Lincoln et al., 1972). This animal had grown simple antlers after being castrated (Pl. 1, Fig. 2) and after the testosterone implant they were cleaned of velvet and remained in hard horn for about a year before being cast. A new set of antlers developed with eight points including branched tops much like those of an intact stag. It seems probable that in this stag the more perfect development of the antler tines was induced by the small amounts of testosterone still being released from the original implant.

In conclusion, it appears that a castrated stag in which the epididymides are left intact develops a more perfect set of antlers than does a normal castrate, perhaps indicating that the epididymis in red deer is capable of releasing minor amounts of androgens into the peripheral circulation.

I am grateful to Dr R. V. Short and Mr J. Fletcher who performed the operations.

\section{REFERENCES}

Frankel, A. I. \& Eik-Nes, K. B. (1970) Metabolism of steroids in the rabbit epididymis. Endocrinology, 87, 646-652.

Hamilton, D. W. (1972) The mammalian epididymis. In Reproductive Biology, pp. 268-337. Eds. H. Balin and S. Glasser. Excerpta Medica, Amsterdam.

Hamilton, D. W. \& FawcetT, D. W. (1970) In vitro synthesis of cholesterol and testosterone from acetate by rat epididymis and vas deferens. Proc. Soc. exp. Biol. Med. 133, 693-695.

Lincoln, G. A. (1970) Reproductive physiology and behaviour of the red deer stag. Ph.D. thesis, Cambridge.

Lincoln, G. A. (1971) The seasonal reproductive changes in the red deer stag (Cervus elephus). F. Zool., Lond. 163, 105-123.

Lincoln, G. A., Guinness, F. \& Short, R. V. (1972) The way in which testosterone controls the social and sexual behaviour of the red deer stag (Cervus elephus). Horm. E̊ Behav. 3, 375-396.

Lincoln, G. A., Youngson, R. W. \& Short, R. V. (1970) The social and sexual behaviour of the red deer stag. F. Reprod. Fert., Suppl. 11, 71-103. 